\title{
CENTRAL EUROPEAN PARTY SYSTEMS AFTER 1990 - STABILIZATION OR CHAOS
}

Jacek WOJNICKI, PhD

Faculty of Political Science and International Studies, University of Warsaw, Poland

jacekwojnicki@uw.edu.pl

\begin{abstract}
The article analyzes the process of the formation of pluralist political scenes in Central and Eastern European countries. The focus of the analysis is five post-communist countries - the Czech Republic, Slovakia, Hungary, Bulgaria and Romania. The first contested parliamentary elections were held in successive months of 1990 (except Poland and Albania), which determined changes in the political scene. In the first transition period, the primary criterion determining the sociopolitical division was the historical factor. On the one hand, there were the so-called post-communist factions related to former ruling parties in the socialist states; on the other, factions created based on broad democratic opposition coalitions. In subsequent years, however, the socioeconomic division along the left-right lines grew in importance, as did the attitude toward the integration processes in Europe and the transformation process itself (along with the lines beneficiaries vs. transition losers). Also noteworthy is a weak ,anchoring” of political parties in their electorates, which has resulted in frequent changes to the structure of parliaments and local government councils.
\end{abstract}

Keywords: Political pluralism, party system, systemic transformation, democratization, elections, sociopolitical divisions.

\section{Introduction}

The pluralization of political scenes in Central European countries is a direct result of the transformation processes of the late 1980s. The subject of our analysis will be several postcommunist countries undergoing the process of systemic transformation from the turn of the 1990s: the Czech Republic, Slovakia, Hungary, Bulgaria, and Romania. There will also be occasional references to other cases - eastern German lands (the former GDR), Poland, and Slovenia. Decisions of communist authorities to introduce political pluralism and call free (or at least contested) parliamentary elections constituted the first steps towards a democratization of the existing political systems. Relevant decisions were first taken among the ruling elites in Poland (January 1989), Hungary (February 1989), Slovenia (September 1989), East Germany, 
Czechoslovakia (November 1989), Bulgaria, and Germany (December 1989). (SobolewskaMyślik 1999; Antoszewski, Herbut 1997; Wojnicki 2004; Fitzmaurice 1998; Dawisha, Parott 1997; Szajkowski 1991). The article will use three research methods: comparative, historical and systemic. They will allow to verify the research hypothesis - whether in the discussed countries we are dealing with the stabilization of party systems or their fragmentation.

The introduction of the freedom to establish and operate political parties meant it was necessary to amend the constitutions in force, adopt democratic electoral legislation and prepare new laws on parties' operation. That is-because existing legal regulations did not provide open competition between party blocs (lists) in parliamentary and local elections. Constitutional amendments involved the removal of provisions about the leading role of the political party in the state and society, the ideological declarations in question could be found in individual constitutional acts (starting from the constitution of Czechoslovakia from July 1960 to the Soviet constitution from October 1977). Constitutional regulations introduced a prohibition on activities of political parties in military forces, prosecutor's offices and courts. In Bulgaria statutory regulations from April 1990 were interesting as they banned the creation of political parties on a religious, ethnic, racial basis. Adopted regulations were quite liberal, new factions were not subject to excessive formal requirements. The model of registration or license was adopted. The number of signatures necessary to register or declare a new political party ranged from 15 (the Polish act) to 251 (the Romanian decree), 750 (the Hungarian legislation), to as many as 1,000 (the Czechoslovak act from 1990). (Chmaj 2006, Zawadzka 1992, Chruściak 1990)

\section{The formation of multiparty systems}

The first contested elections to legislative bodies were held in the discussed region in 1990. The order of elections was determined more by a dynamic social and political situation (e.g. a virtual collapse of the GDR statehood, instability after the „December revolution” in Romania) than any far-reaching scenarios of the elites in power (the agreements at the „triangular table” in Budapest). (Migalski 2005, Fitzmaurice 1998, Ágh 1998, Raciborski 1991; Bugajski 2002)

The new social and political situation was changing the shape of party systems. In the conditions of state socialism (as the then system of governance was usually called)., there was a 
monopolistic party (the casus of Hungary or Romania). In other example it had a monopolistic position while the so-called satellite parties operated formally (Poland, Czechoslovakia, Bulgaria, and GDR). (Rakowska-Harmnstone 1984; Dawisha, Parrot 1997; Żmigrodzki, Sokół 2003)

The political scene in the first period of systemic transformation was mainly divided along the historical criterion which determined the attitude towards the departing political system. The following types of parties could thus be identified: 1/postcommunist; 2/historical; 3/formed around widespread civic and democratic movements; 4/new factions and 5/ethnic and regional ones. To sum up this thread of analysis - postcommunist factions included parties originating from previous ruling factions (e.g., MSZMP, BKP, KSČ, SED, PZPR, PCR). Internal changes in those factions varied considerably -from the adoption of social democratic postulates by MSZP, SdRP, SDL, to the democratic left BSP, the Romanian parties of Petre Roman, and largely cosmetic changes made by KSČM, to the Romanian parties of Ion Iliescu. A research question arose at the same time how to treat formerly allied factions operating in the past systemic reality, like Poland's ZSL, SD, or Bulgaria's BZNS, East Germany's LDPD or CDU). Those parties were usually quite quick to sever their close links with the previous leftist hegemons, branded themselves as centrist or centerright, declared an intention to establish cooperation with factions from the anti-communist opposition. (Wightman 1995; Ágh 1998; Żmigrodzki, Sokół 2003; Sobolewska-Myślik 1999, Raciborski 1997; Bureš, Charvát, Just, Štefek 2012; Szajkowski 1991)

Secondly: historical parties usually meant a reactivation of political factions operating before the communist rule (the turning point of 1947, 1948 only in the case of Czechoslovakia). During the communist rule, they usually operated in exile - in the U.S., London, Paris, or Rome. Permission to operate legally in the country was a milestone in modern history. It is worth nothing. However, that reestablishment of a faction after several dozen years did not automatically mean an electoral success. Notable political factions that obtained the status of a parliamentary party included: Poland's PSL, the Czech social democracy ČSSD, Hungary's FGKP, Bulgaria's BZNS , and Romania's PNL. It is worth noting that in several cases factions existing under the same name united into a single faction. A different case was a unification of the post-communist factions and one wing of the historical parties - the casesof Poland's PSL in May 1990, Romania's PSD in June 2001, and Bulgaria’s BZNS. (Antoszewski 2009, Wojnicki 2004, Ágh 1998, Wightman 1995, 
Krejčí 2006, Jackowicz 1992, Burakowski 2014; Bureš, Charvát, Just, Štefek 2012; Bugajski 2002)

Thirdly: factions originating from the broad front of democratic opposition were created in the early 1990s due to fragmentation of the so-called forum-type coalitions. One case of such fragmentation was the post-Solidarity factions in Poland - the cause of the Centre Agreement (the party of Jarosław Kaczyński), the Liberal Democratic Congress (the party of Donald Tusk, Grzegorz Schetyna and Jan Krzysztof Bielecki), the Democratic Union (the party of Tadeusz Mazowiecki, Bronisław Geremek and Jacek Kuroń) and the Christian National Union (the party of Wiesław Chrzanowski and Stefan Niesiołowski). Similar fragmentation occurred in the Czech Republic (the causes of the Civic Forum), Slovakia (Public Against Violence), and Bulgaria (the Union of Democratic Forces). It is worth noting that the phase of forum-type coalitions did not occur in Hungary, where, as a result of a fairly liberal political regime, proto-parties started forming in the late 1980s. The political factions vying for seats in the parliamentary elections at the turn of March and April 1990 originated from those. (Antoszewski, Herbut, Fiala 2003; Raciborski 1991; Czwołek 2013; Sula 2005; Krejčí 2006, Nalewajko 1997; Bureš, Charvát, Just, Štefek 2012; Bugajski 2002)

The fourth group of political factions involves new organizations, created as a result of current sociopolitical and socioeconomic divisions. They do not represent an „unfreezing” of the social divisions from before the communist rule after several decades. Instead, they relate to current social conflicts, a modern society going through a systemic transformation. Nevertheless also relating to the dynamics of social and political processes in Western Europe. Noteworthy in the discussed group of factions are liberal parties (weakly anchored in the Central and Eastern Europe region in the 1920s and 1930s due to a peripheral nature of capitalist systems), green factions. This group also includes the so-called one issue parties, organizations representing supporters of one crucial social or political issue - parties bringing together young people (e.g., Slovenia's Youth Party - SMS, pensioners' factions - Poland's National Party of Retirees and Pensioners - KPEiR, Slovenia’s DeSUS). (Markowski, Cześnik, Kotnarowski 2015, KosowskaGąstoł 2010, Wojtaszczyk 1992, Krysieniel, Wojnicki 2009; Bugajski 2002) 
The last group of political factions is a direct result of the ethnic structure of the discussed region. The ethnic mosaic is a consequence of the political map of Central and Eastern Europe, directly related to the Yalta and Potsdam order and indirectly related to the Versailles order. After the Treaty of Trianon (1920), the Hungarian population was distributed across several neighboring countries: Slovakia, Romania, Yugoslavia, and Ukraine. In turn, a significant percentage of the Turkish population lives in Bulgaria, particularly in the country's southern regions. Classic ethnic mosaic can be seen in the post-Yugoslav countries - the Hungarian and Italian population in Slovenia, Serbian in Croatia, Albanian in Macedonia or Montenegro. Ethnic divisions translate directly into the political party structure in those countries. Hungarian (SMK, UDMR), Turkish (DPS), Albanian (DUI, DPA) parties represent a fairly stable element of political scenes. (Bugajski 1995, Wojnicki 2004, Wojtaszczyk 1998, Szajkowski 1991)

\section{Sociopolitical divisions}

The formation of political scenes was connected with sociopolitical and socioeconomic conflicts found in particular societies. In political science, they are called „cleavages” (socially significant divisions). Since the turn of the 1990s, various social divisions have emerged in Central and Eastern European countries, resulting in a progressive pluralization of party systems.

Table 1 -social divisions in the post-communist countries

\begin{tabular}{|c|c|c|c|c|c|c|c|c|c|}
\hline country & 1 & 2 & 3 & 4 & 5 & 6 & 7 & 8 & 9 \\
\hline Bulgaria & $\mathrm{M}$ & $\mathrm{M}$ & & & & & $\mathrm{H}$ & & \\
\hline Croatia & & & & & & $\mathrm{H}$ & $\mathrm{H}$ & $\mathrm{M}$ & \\
\hline Czech Republic & & $\mathrm{M}$ & & & & & $\mathrm{H}$ & & \\
\hline Poland & & & $\mathrm{H}$ & $\mathrm{H}$ & & & $\mathrm{H}$ & & \\
\hline Romania & $\mathrm{M}$ & & & & & $\mathrm{H}$ & $\mathrm{H}$ & & \\
\hline
\end{tabular}




\begin{tabular}{|c|c|c|c|c|c|c|c|c|c|}
\hline Slovakia & M & M & & & & H & H & M & \\
\hline Slovenia & & $\mathrm{H}$ & $\mathrm{M}$ & & & $\mathrm{H}$ & $\mathrm{H}$ & & $\mathrm{M}$ \\
\hline Hungary & & & $\mathrm{H}$ & $\mathrm{M}$ & & & $\mathrm{H}$ & & \\
\hline
\end{tabular}

Source: (Siaroff, A., 2000)

Types of conflicts: 1/denominational, 2/regional/ethnic, 3/religious, 4/urban-rural, 5/support for the system, 6/nationalism, 7/socioeconomic, 8/foreign policy, 9/postmaterialism

\section{Levels: M-moderate, $\mathbf{H}$ - high}

The proposed systematization of social conflicts in Central and Eastern European countries makes it possible to arrive at some conclusions. Firstly: what all the discussed countries share is a socioeconomic conflict underpinning the development of political factions along the left-right lines. Over the years, as market changes advance, it has been strengthening as a factor that defines parties. Secondly: the religious factor which is of crucial importance for confessional factions is found both in Orthodox (Bulgaria, Romania) and Catholic countries (Slovakia) where other religions are present as well - Islam (Bulgarian Turks), Hungarian and German Catholics in Romania. Thirdly: also significant is the conflict between the center and the regions as well as the ethnic-based one, found at a moderate level in three countries - Bulgaria, the Czech Republic, and Slovakia, at a high level in Slovenia. Fourthly: the religious factor of crucial importance for confessional factions is found in countries where the Catholic religion is dominant (Poland, Hungary, Slovenia). Fifthly: it is interesting that the „urban-rural” factor, key to social divisions in the pre-communist period, has lost its political importance. Its substantial importance is still seen in only two regional countries - Poland and Hungary. Sixthly: nationalist issues remain essential just like in the interwar period. It is quite understandable given the relatively late nationmaking and state-making processes in the discussed region of the Old Continent (e.g., Croatia, Romania, Slovakia, and Slovenia). Seventhly, foreign policy's importance for forming social divisions can be considered substantial only in Croatia and Slovakia. In both cases, it is a consequence of undemocratic rule in the 1990s (F. Tudjman, V. Mečiar) which resulted in delayed 
accession of both countries to defense and European institutions concerning neighboring countries (Croatia with Slovenia and Slovakia with the Visegrad Group countries: Poland, the Czech Republic, and Hungary). Finally, it is worth adding that post-material values' substantial importance only in the case of Slovenia quite accurately illustrates the civilizational level of the wealthiest post-communist Central European country. (Siaroff 2000)

In the first period of the transformation processes, historical divisions were the most important, pitting post-communist factions against factions originating from the democratic opposition circles. The first coalition built over those divisions was the coalition backing the government of Janez Drnovšek in Slovenia (April 1992), then the political foundation of the government of Jozsef Moravčik in Slovakia (March 1994) and the political basis of the government of Gyula Horn in Hungary (May 1994). In the first case, the decisive factor was a rising importance of socioeconomic divisions and a centrist position of the social-liberal LDS faction headed by Janez Drnovšek. In the Slovak case until 1998, a major sociopolitical division defined political factions around supporters and opponents of the undemocratic rule exercised by Vladimir Mečiar. In the Hungarian case, on the other hand, the post-communist faction (MSZP) held an absolute majority in the National Assembly after the election in May 1994. Its coalition with the socialliberal SZDSZ was supposed to document the credibility of the pro-democratic and pro-market reorientation of the Hungarian socialists. In addition to that, in the previous parliamentary term (1990-1994), both factions remained in opposition to the center-right cabinet of J. Antall and P. Bőrőss. (Antoszewski, Herbut, Fiala 2003; Wojnicki 2004; Wightman 1995; Krejčí 2006; Fitzmaurice 1998; Bugajski 2002)

For factions originating from the anti-communist opposition circles, the most important axes of the conflict centered around two issues: attitude to the pace and scope of economic reforms in Central and Eastern European countries, and relations with post-communist parties. Including the issue of accounting for the communist past symbolized by decommunization and vetting of former collaborators with security services. The category of factions advocating for the swift and determined introduction of free-market institutions included Poland's Democratic Union (UD) and the Liberal Democratic Congress (KLD), the Czech Republic's Civic Democratic Party (ODS), the Slovak Democratic and Christian Union (SDKU), Bulgaria's Union of Democratic Forces 
(SDS). (Migalski 2005, Wojtaszczyk 1998, Sobolewska-Myślik 1999, Jackowicz 1992, Ágh 1998, Szajkowski 1991; Bureš, Charvát, Just, Štefek 2012)

In the case of the federal countries (Yugoslavia, Czechoslovakia), in turn, an essential axis of political conflict in the early 1990s was the attitude of individual factions to the restructuring of the union state and independence demands. Parties in Slovenia, Croatia, and Slovakia should be put in this context. In the first case, we should mention the Slovenian National Party (SNS), in the second - the Croatian Democratic Union (HDZ), and in the third - the Movement for a Democratic Slovakia (HZDS). (Bugajski 1995; Dawisha, Parott 1997; Krejčí 2006; Krysieniel, Wojnicki 2009)

In the next period of the transformation processes (after 2000), the issue of attitude to European integration and Europeanization processes (in the context of the of the countries in question to European institutions) and attitude to the ongoing transformation processes became the factor differentiating the political scene. The first axis of division shaped parties as 1/Euroenthusiastic, 2/Euro-realistic, and 3/Euro-sceptic. Slogans of distance towards the integration processes were voiced by 1/the League of Polish Families and „Self-Defense” in Poland, 2/Jobbik in Hungary, 3/Ataka in Bulgaria, 4/People’s Party „Our Slovakia”, or 5/the Greater Romania Party (PMR). In turn, the moderate distance towards the integration processes was expressed by Law and Justice in Poland and FIDESZ in Hungary (who called themselves Euro-realists). (Antoszewski 2009, Kosowska-Gąstoł 2010, Wojnicki 2004, Czwołek 2013)

A negative attitude to the transformation processes meant criticism of the adopted model of political and economic changes after 1989 as too liberal (without social support for the poorer segments of society) and as an insufficient rupture with the previous political system (petrifaction of post-communist influence in political and social-economic life). Such slogans were voiced at the turn of the 21 st century by conservative factions - Law and Justice (PiS), FIDESZ, and the Slovenian Democratic Party (SDS). (Antoszewski 2009, Kosowska-Gąstoł 2010, Wojnicki 2004; Bugajski 2002)

\section{The typology of party systems}

It is worth invoking the opinion of Polish scholars of political systems, A. Antoszewski and R. Herbut, who pointed to the following as they analyzed emerging party systems: $1 /$ no 
development of permanent sociopolitical divisions in the post-communist countries of Central and Eastern Europe (defined as a stable relationship between the society and a particular political faction), 2/formation of the so-called politicization of group interests, and 3/low social ,,anchoring” of parties. The result of these social attitudes and behaviors is substantial electoral volatility. (Antoszewski, Herbut 1997, Markowski 2015, Lewis, Markowski 2011)

Polish researcher of political party issues Marek Sobolewski listed three essential functions of parties: 1/shaping political opinions and attitudes; 2/electoral (creating a political program and selecting candidates), and 3/governing (being in charge of state authorities and government accountability offices). (Sobolewski 1977: 300) In this typology, it is worth mentioning the issue of alternation of political power in Central and Eastern European countries after 1989. We have witnessed a few scenarios: 1/alternation of power after following the first contested elections (indirectly Poland after 1989, Hungary, GDR, Czechoslovakia, Slovenia, Croatia - in 1990); 2/the first elections confirmed a stable position of the post-communist factions (Bulgaria, Romania - in 1990, Albania in 1991, Serbia and Montenegro - in 1990); 3/also subsequent parliamentary elections did not make the alternation of state power - Romania in 1996 (third election), Serbia until 2000 (fourth election). It is worth mentioning that in the case of Montenegro, there has been no alternation of power until 2020. (Chruściak 1990; Krejčí 2006; Ramet 2012)

Let us take a look now at the typologies of party systems and their practical application in the discussed region of the Old Continent. Italian political scientist and scholar of political parties Giovanni Sartori proposed the following typologies of party systems: 1/a two-party system with alternating governments; 2/moderate pluralism; 3/polarized pluralism; 4/a system of a dominant party in moderate pluralism. In the second model, there is usually little ideological distance between the main factions, with a desire for the polar formation of parliamentary coalitions, and dominance of centripetal competition between parties without anti-system factions. The third scenario involves a trend towards centrifugal political competition. Consequently, these elements threaten the legitimacy of the political system. The above model can be formed in two variants: polarized pluralism with fundamental opposition on the left and right, and polarized pluralism with centrist parties capable of governing. (Sartori 1976) 
The model of moderate pluralism has been seen in the Czech Republic (until 2010), Hungary (until 2010), Romania since the 1992 election, and Bulgaria since 1990. The most fragmented political scene, has been found in Slovakia, which is marked by the highest electoral volatility and frequent changes of factions present in the National Council of the Slovak Republic. In turn, a system of a dominant party in moderate pluralism formed in Hungary after 2010, with a unique position held by FIDESZ, was occasionally seen in Romania - the early 1990s - the dominance of FSN, and the Social-Liberal Union after 2012. We should also mention the presence of anti-system factions that were left out of government and parliamentary coalitions. The status of such parties was held for many years by the Czech communists from KSČM and the Czech republicans from SPR-RSČ, the Hungarian populists from MIÉP (after this nationalist faction's break away from MDF) and Jobbik, the Romanian nationalists from PRM, the Bulgarian nationalists from Ataka and the Slovak nationalists from LSNS. (Barański 2018, Krejčí 2006; Kopeček 2007; Bajda 2010, Burakowski 2014, Markowski, Wnuk-Lipiński 2001; Bureš, Charvát, Just, Štefek 2012)

The typology by Jean Blondel assumed the presence of the following partisanship models: 1/a two-party system; 2/a two-and-a-half party system; 3/a multiparty system with a dominant party; 4/a multiparty system without a dominant party. In the second variant, a vital role is played by a complementary party necessary to form a government and parliamentary coalition. The third variant assumes that one faction can exercise governing power even if other parliamentary factions form a broad governing coalition. (Blondel 1968)

Referring to this typology, we can point to the development of a two-bloc system (from 2001) with a unique position of a pivotal party for Turkey's DPS, which has supported both centerleft and center-right governing coalitions in Bulgaria's National Assembly. Poland's PSL was a similar case until 2006, having the potential to form centre-right and centre-left coalitions. In the Czech example, a pivotal position was held by the Christian Democratic People's Party. The third variant has developed in its fullest form in Hungary after 2010, with a dominant position of FIDESZ. The fourth formula has been the most popular in the discussed region - a multiparty system without a dominant party. Such examples can be found in Slovakia, the Czech Republic, Romania and Bulgaria (except a few turning points - short-lived domination of BSP or SDS). 
(Barański 2018; Kopeček 2007; Kowalczyk, Tomczak 2007; Kosowska-Gąstoł 2010; Burakowski 2014; Góralczyk 2000; Csizmadia, Lakatos 2016; Bureš, Charvát, Just, Štefek 2012)

In the view of Gordon Smith, three models of party systems can be identified according to the government formation criterion: 1/balanced, 2/unbalanced, and 3/dispersed. In this typology, what matters is the existence of political polarization, the domination of one political faction, or there is no polarization of the political scene and several factions score similar election results. (Smith 1989, 1992)

In the period after 1989, the domination of a political faction was occasionally seen in postcommunist countries. Such cases include The National Salvation Front in post-revolution Romania (1990-1991), Fidesz after 2010, Law and Justice after 2015 (though without domination in the upper parliamentary chamber after the election in autumn 2019). The first parliamentary elections in the Czech Republic and Hungary showed the features of a balanced model, there was an alternation between the leftist $\breve{C S S D}$ and the conservative-popular ODS in the Czech case (until 2006), and between the leftist MSzP and the conservative FIDESZ in the Hungarian case (until 2006). Also in the case of Bulgaria until 2001, there was a balanced political rivalry between the „blues” from the Union of Democratic Forces and the „red” socialists from BSP. In turn, the domination of Slovenia's LDS stemmed from growing support for this faction in successive elections (from 1992 to 2000 - support rising from 24\% to 36\%) and centripetal political rivalry and pragmatic creation of parliamentary and governmental coalitions. Another example was a declining dominance of Slovakia's HZDS, which lost support in successive elections from 1992 to 2006, but kept coming first in elections (a drop from 34\% to 19\%). (Czwołek 2013, Kopeček 2007, Krejčí 2006; Burakowski 2014, Krysieniel 2009, Csizmadia, Lakatos 2016; Bureš, Charvát, Just, Štefek 2012)

In the analyzed post-communist countries (including the Czech Republic, Slovakia, Hungary, Bulgaria and Romania), 44 parliamentary elections took place after 1990. In the Czech and Slovak case, the parliamentary election held in June 1990, still within the then federal state, is also included in our analysis. That is because it resulted in the formation of diverse political scenes of the independent Czech Republic and Slovakia after 1992. The first observation relates to the scale of victory achieved by individual political factions in the period examined. 
Table 2 - the scale of the biggest parliamentary victory in the post-communist countries

\begin{tabular}{|c|c|c|c|c|}
\hline Country & 1 & 2 & 3 & 4 \\
\hline Bulgaria & $\begin{array}{c}\text { SDS } \\
1997 \\
52,3 \%\end{array}$ & $\begin{array}{c}\text { BSP } \\
1990 \\
47,5 \%\end{array}$ & $\begin{array}{c}\text { NDSV } \\
2001 \\
42,7 \%\end{array}$ & $\begin{array}{c}\text { GERB } \\
2013 \\
39,7 \%\end{array}$ \\
\hline $\begin{array}{l}\text { The Czech } \\
\text { Republic }\end{array}$ & $\begin{array}{c}\text { ODS } \\
2006 \\
35,4 \%\end{array}$ & $\begin{array}{c}\text { ČSSD } \\
1998 \\
32,3 \%\end{array}$ & $\begin{array}{c}\text { ČSSD } \\
2006 \\
32,3 \%\end{array}$ & $\begin{array}{c}\text { ANO } \\
2011 \\
2017 \\
29,6 \%\end{array}$ \\
\hline Romania & $\begin{array}{c}\text { FSN } \\
1990 \\
66,7 \%\end{array}$ & $\begin{array}{c}\text { USL } \\
2012 \\
58,6 \%\end{array}$ & $\begin{array}{c}\text { PSD } \\
2016 \\
45,5 \%\end{array}$ & $\begin{array}{c}\text { DA } \\
2004 \\
36,8 \%\end{array}$ \\
\hline Slovakia & $\begin{array}{c}\text { SMER } \\
2012 \\
44,4 \%\end{array}$ & $\begin{array}{c}\text { SMER } \\
2010 \\
34,8 \%\end{array}$ & $\begin{array}{c}\text { HZDS } \\
1994 \\
34,7 \%\end{array}$ & $\begin{array}{c}\text { HZDS } \\
1992 \\
34,4 \%\end{array}$ \\
\hline Hungary & $\begin{array}{c}\text { FIDESZ } \\
2010 \\
52,7 \%\end{array}$ & $\begin{array}{c}\text { FIDESZ } \\
2018 \\
49,3 \%\end{array}$ & $\begin{array}{c}\text { FIDESZ } \\
2014 \\
44,9 \%\end{array}$ & $\begin{array}{c}\text { MSZP } \\
2006 \\
43,2 \%\end{array}$ \\
\hline
\end{tabular}

Source: http://www.parties-and-elections.eu/countries.html (08.04.2020)

Abbreviations: SDS - the Union of Democratic Forces, BSP- the Bulgarian Socialist Party, GERB - Citizens for European Development of Bulgaria, NDSV - the National Movement for Simeon II, ODS - the Civic Democratic Party, ČSSD - the Czech Social Democratic Party, ANO 2011- Action of Dissatisfied Citizens, FSN - the National Salvation Front, USL- the Social Liberal Union, PSD- the Social Democratic Party, DA- the „Justice and Truth” Alliance, SMER - 
Direction, HZDS - the Movement for a Democratic Slovakia, FIDESZ - the Federation of Young Democrats - Hungarian Civic Party, MSZP - the Hungarian Socialist Party

Analysis of these election results shows that winning factions have occasionally obtained an absolute parliamentary majority enabling a one-party cabinet to be formed in the discussed countries. This situation has occurred most often in Hungary - FIDESZ has won an absolute majority in the National Assembly three times after 2010. In Romania, in turn, an absolute majority has been won twice by broad coalitions of factions - the postcommunist FSN in May 1990 (66.7\%) and the centre-left USL (58.6\%) in 2012. Both coalitions broke up rather quickly, so their domination in the political scene did not last long. In Slovakia, however, only following the election in 2012 did the victorious SMER hold an absolute majority in the National Council of the Slovak Republic (83 mandates out of 150). In Bulgaria, in turn, winning factions (or coalitions) have obtained an absolute majority in the National Assembly three times - the broad democratic coalition led by SDS in 1997 and the postcommunist BSP twice, in June 1990 and in December 1994. It is worth noting that the faction of former tsar Simeon II (NDSV) came very close to winning the required majority of seats in 2001 (half the seats, 120 out of 240). The Chamber of Deputies in the Czech Republic is yet to see an absolute majority for a winning faction. (Kosowska-Gąstoł 2010, Antoszewski 2009, Ramet 2012, Krejčí 2006; Burakowski 2014, Barański 2018, Jackowicz 1992, Csizmadia, Lakatos 2016; Bureš, Charvát, Just, Štefek 2012)

Table 3 - the scale of the smallest parliamentary victory in the post-communist countries

\begin{tabular}{|c|c|c|c|}
\hline country & 1 & 2 & 3 \\
\hline Bulgaria & GERB & BSP & - \\
& 2013 & 2005 & \\
& $30,5 \%$ & $31,0 \%$ & \\
\hline $\begin{array}{c}\text { The Czech } \\
\text { Republic }\end{array}$ & ČSSD & ČSSD & ODS \\
& 2013 & 2010 & 1996 \\
& $20,5 \%$ & $22,1 \%$ & $29,6 \%$ \\
\hline
\end{tabular}




\begin{tabular}{|c|c|c|c|}
\hline Romania & PSD & PSD & PSD \\
& 2008 & 2000 & 1992 \\
& $33,1 \%$ & $36,6 \%$ & $27,7 \%$ \\
\hline Slovakia & OL'aNO & HZDS & - \\
& 2020 & 2002 & \\
& $25,0 \%$ & $19,5 \%$ & \\
\hline Hungary & MSZP & MSZP & MDF \\
& 1994 & 1998 & 1990 \\
& $33,0 \%$ & $32,9 \%$ & $24,2 \%$ \\
\hline
\end{tabular}

Source: http://www.parties-and-elections.eu/countries.html (08.04.2020)

Abbreviations: BSP- the Bulgarian Socialist Party, GERB - Citizens for European Development of Bulgaria, ODS - the Civic Democratic Party, ČSSD - the Czech Social Democratic Party, PSD- the Social Democratic Party, OL'aNO- Ordinary People and Independent Personalities, HZDS - the Movement for a Democratic Slovakia, MDF - the Hungarian Democratic Forum, MSZP - the Hungarian Socialist Party

Analysis of the smallest support for a winning faction in parliamentary elections makes it possible to draw the following conclusions. A situation of the most fragmented parliament has been seen four times, twice each in the Czech Republic and Slovakia. Thus, the winning faction has twice won less than 23\% support in the Chamber of Deputies - ČSSD in the elections of 2010 and 2013. In Slovakia, in the election to the National Council in 2002, the victorious HZDS won less than $20 \%$ of the votes cast, and in the last election in March 2020, OL'aNO won about a quarter of the votes cast. Both countries symbolized political scene fragmentation following the break-ups of their opinion poll leaders - in the Czech Republic, as a result of the weakened political influence of the previous archrivals - ODS and ČSSD; in Slovakia, as a result of decreased public support for HZDS (2002) and SMER (2020). Moreover in the Hungarian case, the most fragmented parliament was elected in March 1990 when the winning faction registered support of less than 1 in 4 votes cast. In the case of the Slovak party system, a few stages of its development 
can be identified - 1/a two-bloc rivalry (1992-1998), 2/a broad coalition government (1998-2006), and 3/a multiparty system with a dominant faction (2006-2016) (Kosowska-Gąstoł 2010, Antoszewski 2009, Burakowski 2014, Krejčí 2006; Barański 2018, Ramet 2012, Fitzmaurice 1998; Bureš, Charvát, Just, Štefek 2012)

Table 4 - the scale of support for new factions in the post-communist countries

\begin{tabular}{|c|c|c|c|c|c|c|}
\hline Country & 1 & 2 & 3 & 4 & 5 & 6 \\
\hline Bulgaria & 2001 & 2005 & 2009 & 2013 & 2014 & 2017 \\
& $42,7 \%$ & $19,7 \%$ & $39,7 \%$ & $3,7 \%$ & $26,1 \%$ & $4,2 \%$ \\
\hline $\begin{array}{c}\text { The Czech } \\
\text { Republic }\end{array}$ & 1998 & 2002 & 2006 & 2010 & 2013 & 2017 \\
& $8,6 \%$ & - & $6,3 \%$ & $27,6 \%$ & $25,6 \%$ & $26,6 \%$ \\
\hline Romania & 2004 & 2012 & 2016 & - & - & - \\
\hline Slovakia & $31,5 \%$ & $14,0 \%$ & $19,9 \%$ & & & \\
& 2002 & 2006 & 2010 & 2012 & 2016 & 2020 \\
\hline
\end{tabular}

Source: http://www.parties-and-elections.eu/countries.html (08.04.2020)

The last issue to be analyzed involves the scale of fragmentation of new political factions. The bigger the scale, the lower the stability of the party systems and parliamentary elite of individual countries. Replacement of factions in legislatures is also indicative of anti-establishment sentiments in the society and a low level of trust in the political class. That is why new parties and 
political factions (which often do not define themselves as parties) win considerable public support and obtain parliamentary seats. (Markowski 2015; Lewis, Markowski 2011)

The presented table indicates that the highest level of parliamentary instability is found in Bulgaria and Slovakia. In the first case, we have witnessed it since 2001, after a loss of trust in the major factions of the Bulgarian transformation - the „reds” from BSP and the „blues” from SDS. Then it is time for former tsar Simeon II (NDSV) to enter the political scene, as a temporary savior. GERB and the nationalist Ataka emerge in the next election. Considerable instability has also been seen in Slovakia. On the one hand, it resulted from a weakening of the leading faction thus far HDZS, which opened a window for populist and conservative-popular factions. On the other hand, the center-right specter of the political scene, emerging in opposition to the then regime of Vladimir Mečiar, focusing on big city population and intelligentsia, was yet to stabilize. Therefore, numerous factions popped up invoking liberal slogans, created by both businessmen and scientists. The last election to the National Council (March 2020) demonstrated a continuation of the process, particularly in the context of a weakening position of Smer, which has dominated since 2006. (Barański 2018; Czwołek 2013, Krejčí 2006; Kosowska-Gąstoł 2010, Antoszewski 2009; Kopeček 2007)

In the Czech Republic, in turn, the process of destabilization of the party system strengthened after 2010 as a result of the weakened popularity of the existing hegemons - the conservative ODS and the leftist ČSSD. Two factions were created which claimed to be „powerbrokers" in the political scene. The first project, appealing to the conservative and liberal electorate, was TOP' 09 created around popular politician Karel Schwarzenberg. Moreover the other faction rode a wave of discontent with the political elites and was founded by brisk businessman and economic heavyweight in the Republic, Andrej Babiš - ANO 2011. (Barański 2018; Kosowska-Gąstoł 2010; Krejčí 2006; Bureš, Charvát, Just, Štefek 2012)

Romania, in turn, has had a rather stable political scene, broad center-right (CDR in 1992 and DA in 2004) or eclectic coalitions (USL in 2012) were created, but they brought together factions and politicians who had already sat in the parliament before. Thus, it would be difficult to treat them as formally new political factions. Some changes in this regard can be seen since 2012, as a result of rising mistrust in the existing political elite, both on the right and left of the political 
specter. New parties claiming to fight corruption and criminal links between the political class and business and officials were created. (Burakowski 2014, Kosowska-Gąstoł 2010, Antoszewski 2009, Bugajski 2002)

A fairly stable political scene has also developed in Hungary. The biggest quantitative change was the entry of nationalist Jobbik into the National Assembly in April 2010. However, the place vacated by the social-liberal SzDSz was not permanently taken up by liberal factions and those appealing to the big city electorate. (Bugajski 2002, Czwołek 2013, Kosowska-Gąstoł 2010, Antoszewski 2009, Csizmadia, Lakatos 2016)

\section{Summary}

This analysis included the issues of the formation and stabilization of party systems in Central and Eastern European countries. The pluralization of political scenes was a significant element of the transformation processes launched at the turn of the 1990s. The emerging party systems had numerous common features while taking into account the specific nature of a particular country and traditions of homegrown political institutions. In the initial period of the systemic transition (the first ten-fifteen years), the fundamental sociopolitical division involved the historical criterion. Apart from a few examples (Slovenia in 1992, Hungary in 1994 and 2002, Romania in 1996 and Slovakia in 1994), political factions were divided, per their origins, into postcommunist ones and those originating from broad democratic opposition camps. Another common feature of the countries in question was a (smaller or bigger) failure of the so-called historical parties, which failed to reactivate after several dozen years of outlawing. The only example of a successful reactivation of such a party is the Czech social democracy (ČSSD) and, to a lesser extent, Poland's PSL. Another common feature of the party systems was a ,weak anchoring" of factions in the electorate. It resulted in considerable voting volatility and changes in the structure of the political scenes. The most stable party systems developed in Hungary and Romania. In turn, the fairly stable Czech party system underwent substantial fragmentation after 2010 due to a weakened position of the previously dominant two factions: ODS and ČSSD. The most unstable party systems were found in Slovakia and Bulgaria. In the first case, it resulted from a weakened position of the dominant factions - HZDS and SMER, as well as an inability to form 
an effective opposition bloc to these parties. In the other case, we saw increasing mistrust in the political elites symbolized by the camp of the „reds” from BSP and the „blues” from SDS. They were firstly exploited by former tsar Simeon II (NDSV) and then by GERB and its leader Boyko Borisov who profiled himself as a „strongman”.

\section{References}

1. Ágh, A., 1998, The Politics of Central Europe, London: SAGE; 1998

2. Antoszewski, A., 2009, Partie i systemy partyjne państw Unii Europejskiej na przełomie wieków, Toruń: Wydawnictwo Adam Marszałek

3. Antoszewski, A., Herbut, R, Fiala, P., 2003, Partie i systemy partyjne Europy Środkowej, Wrocław; Uniwersytet Wrocławski

4. Antoszewski, A., Herbut, R., 1997, Demokracje Europy Środkowo-Wschodniej w perspektywie porównawczej, Wrocław: Uniwersytet Wrocławski

5. Bajda, P., 2010, Elity polityczne na Słowacji w latach 1989-2010: kręta droga do nowoczesnego państwa, Warszawa: Instytut Studiów Politycznych PAN: Instytut Wydawniczy Pax

6. Barański, M., et alii, 2018, Współczesne partie i systemy partyjne państw Grupy Wyszehradzkiej w procesie demokratyzacji, Katowice: Wydawnictwo Uniwersytetu Śląskiego

7. Blondel, J., Party Systems and Patterns of 'Government in Western Democracies', „Canadian journal of Political Science”, 1 /2 (1968), 180-203

8. Bugajski, J., 1995, Ethnic politics in Eastern Europe: a guide to nationality policies, organizations, and parties: with a new postscript, Armonk, N.Y. ; London: M. E. Sharpe

9. Bugajski, J., 2002, Political Parties of Eastern Europe: A Guide to Politics in the PostCommunist Era, Armonk-New York: M.E. Sharpe,

10. Burakowski, A., 2014, System polityczny współczesnej Rumunii, Warszawa: Instytut Studiów Politycznych PAN; Kraków Ośrodek Myśli Politycznej

11. Bureš, J, Charvát, J., Just, P., Štefek, M., 2012, Česká demokracie po roce 1989. Institucionální základy českého politického systemu, Praha: Grada Publishing 
12. Chmaj, M., 2006, Wolność tworzenia $i$ działania partii politycznych: studium porównawcze, Olsztyn: Wydawnictwo Uniwersytetu Warmińsko-Mazurskiego

13. Chruściak, R., Koperska, T., 1990, Nowe ordynacje wyborcze Bułgarii, Czechosłowacji, NRD, Rumunii i Węgier: materiały prawno-porównawcze, Warszawa: Biblioteka Sejmowa

14. Csimadia, E., Lakatos, J., 2016, Fenomem Fideszu. Alternatywne podejście, w: Przekraczając uprzedzenia i entuzjazm, red. Sullivan, J., Póczy, K., Kraków-Budapeszt: Ośrodek Myśli Politycznej- Danube Institute

15. Czwołek, A., Nowak-Paralusz, M., Gawron-Tabor, K., 2013, Partie i systemy partyjne Europy Środkowo-Wschodniej: dwie dekady doświadczeń, Toruń: Wydawnictwo Naukowe Uniwersytetu Mikołaja Kopernika

16. Dawisha, K., and Parrot, B., 1997, The consolidation of democracy in East-Central Europe, Cambridge; New York: Cambridge Univ. Press

17. Dawisha, K., and Parrot, B., 1997, Politics, Power and the Struggle for Democracy in South-East Europe, Cambridge; New York: Cambridge Univ. Press

18. Fitzmaurice, J., 1998, Politics and government in the Visegrad countries: Poland, Hungary, the Czech Republic and Slovakia, Basingstoke; New York: Palgrave

19. Góralczyk, B., 2000, Węierski pakiet, Warszawa: Studio Wydawnicze Familia

20. Grzybowski, M., Zięba, A., 1996, Współczesne systemy partyjne wybranych państw europejskich, Kraków: Wydaw. UJ: nakł. WPiAUJ

21. Harmstone-Rakowska, T., 1984, Communism in Eastern Europe, Bloomington; London: Indiana University Press

22. Jackowicz, J., 1992, Bułgaria: od rządów komunistycznych do demokracji parlamentarnej: 1988-1991, Warszawa: ISP. PAN

23. Kopeček, L., 2007, Politické strany na Slovensku 1989 až 2006, Brno: Centrum pro studium demokracie a kultury

24. Kosowska-Gąstoł, B., 2010, Systemy partyjne państw Unii Europejskiej, Kraków: Wydawnictwo Uniwersytetu Jagiellońskiego

25. Kowalczyk, K., Tomczak, Ł, 2007, Czechy, Polska, Ukraina: partie i systemy partyjne: stan i perspektywy, Toruń: Wydawnictwo Adam Marszałek

26. Krejčí, O, 2006, Nová kniha o volbách, Praha: Professional Publishing 
27. Krysieniel, K., Wojnicki, J., 2009, Partie i systemy partyjne państw bytej Jugosławii: (Bośnia i Hercegowina, Chorwacja, Czarnogóra, Macedonia, Serbia, Stowenia), Pułtusk: Akademia Humanistyczna im. Aleksandra Gieysztora; Warszawa: Oficyna Wydawnicza ASPRA-JR

28. Lewis, P., G. and Markowski, R., 2011, Europeanising party politics?: comparative perspectives on central and Eastern Europe, Manchester; New York: Manchester University Press

29. Markowski, R., Cześnik, M., Kotnarowski, M, 2015, Demokracja - gospodarka - polityka: perspektywa polskiego wyborcy, Warszawa: Wydawnictwo Naukowe Scholar

30. Markowski, R., Wnuk-Lipiński, E., 2001, Transformative paths in Central and Eastern Europe, Warsaw: Instytut Studiów Politycznych Polskiej Akademii Nauk

31. Michalak, B., 2010, Partie polityczne i systemy partyjne: zarys wykładu, Warszawa: Wydawnictwo Wyższej Szkoły Pedagogicznej TWP

32. Migalski, M., 2005, Partie i systemy partyjne państw Europy Środkowej i Wschodniej, Sosnowiec: Wyższa Szkoła Zarządzania i Marketingu: Abako

33. Nalewajko, E., 1997, Protopartie i protosystem?: szkic do obrazu polskiej wielopartyjności, Instytut Studiów Politycznych Polskiej Akademii Nauk

34. Raciborski, J., 1991, Wybory i narodziny demokracji w krajach Europy Środkowej $i$ Wschodniej, Warszawa: Agencja Scholar

35. Raciborski, J., 1997, Polskie wybory: zachowania wyborcze spoleczeństwa polskiego w latach 1989-1995, Warszawa: Wydawnictwo Naukowe "Scholar"

36. Ramet, S., P., 2012, Polityka Europy Środkowej i Poludniowo-Wschodniej po 1989, Warszawa: Książka i Wiedza

37. Sartori, G., 1976, Parties and Party Systems: A framework for analysis, Cambridge University Press

38. Siaroff, A., 2000, Comparative European Party Systems. An Analysis of Parliamentary Elections since 1945, New York-London

39. Smith, G., 1989, Politics in Western Europe: A Comparative Analysis, 5th Edition Aldershot: Gower

40. Smith, G., 1992, Życie polityczne w Europie Zachodniej, Londyn: Puls (polskie wydanie) 
41. Sobolewska-Myślik, K, 1999, Partie i systemy partyjne w Europie Środkowej po 1989 roku, Kraków: Wydawnictwo Akademickie

42. Sobolewska-Myślik, K., Kosowska-Gąstoł, B., Borowiec, P., Organizational structures of political parties in Central and Eastern European countries, Kraków: Jagiellonian University Press

43. Sobolewski, M., 1997, Partie i systemy partyjne świata kapitalistycznego, Warszawa: Wydawnictwo PWN

44. Stolarik, M., M., 2016, The Czech and Slovak Republics Twenty years of Independence, 1993-2013, Budapest, Hungary; New York, New York: CEU Press

45. Sula, P., 2005, System partyjny Wegier, Wrocław: Uniwersytet Wrocławski

46. Szajkowski, B., 1991, New political parties of Eastern Europe and the Soviet Union, Harlow: Longman Group

47. Wightman, G., 1995, Party formation in East-Central Europe: post-communist politics in Czechoslovakia, Hungary, Poland and Bulgaria, Aldershot; Brookfield: E. Elgar

48. Wojnicki, J., 2004, Kształtowanie się systemów wielopartyjnych $w$ Europie Środkowowschodniej. 1989-2004, Pułtusk: Wyższa Szkoła Humanistyczna im. A. Gieysztora

49. Wojtaszczyk, K.,A., 1998, Partie polityczne w państwie demokratycznym, Warszawa: Wydaw. Szkolne i Pedagogiczne

50. Wojtaszczyk, K.,A., 1992, Współczesne systemy partyjne, Warszawa: Wydaw. Naukowe PWN

51. Zawadzka, B., 1992, Zmiany systemu politycznego w ustawodawstwie państw Europy Środkowej i Wschodniej 1989-1991, Warszawa: Agencja Scholar

52. Żmigrodzki, M., Sokół, W., 2003, Współczesne partie i systemy partyjne: zagadnienia teorii i praktyki politycznej, Lublin: Wydaw. Uniwersytetu Marii Curie-Skłodowskiej 